\title{
Market Discounts and Shareholder Gains for Placing Equity Privately
}

\author{
MICHAEL HERTZEL and RICHARD L. SMITH*
}

\begin{abstract}
Despite selling at substantial discounts, private placements of equity are associated with positive abnormal returns. We find evidence that discounts reflect information costs borne by private investors and abnormal returns reflect favorable information about firm value. Results are consistent with the role of private placements as a solution to the Myers and Majluf underinvestment problem and with the use of private placements to signal undervaluation. We also find some evidence of anticipated monitoring benefits from private sales of equity. For the smaller firms that comprise our sample, information effects appear to be relatively more important than ownership effects.
\end{abstract}

EQUITY PRIVATE PLACEMENT IS among the least-studied methods of corporate capital raising. The few studies that have been published raise provocative questions. An early study by the SEC (1971) reports average discounts of about 30 percent for private placements of unregistered shares. A few small scale studies in the tax-accounting literature find discounts on unregistered shares can exceed 50 percent (Arneson (1981a, 1981b), Friedlob (1983), and Johnson and Racette (1981)). In more recent studies, Wruck (1989) reports smaller but still substantial average discounts and Silber (1991) reports discounts on restricted stock averaging 34 percent. Although the illiquidity associated with unregistered stock provides a partial explanation, it is not clear why investors require, and firms are willing to accept, such sizeable discounts. Nor is it clear why registered shares often are privately placed at substantial discounts. The stock price reaction to private placement announcements is also puzzling. Wruck, for example, finds positive announcement period abnormal returns averaging 4.4 percent. ${ }^{1}$ The positive reaction contrasts with the negative market reaction to public equity issue announce-

\footnotetext{
*Department of Finance, College of Business, Arizona State University. We thank Hank Bessembinder, Bart Broadman, John Byrd, Kalok Chan, Saeyoung Chang, Jack Cooney, Espen Eckbo, Paul Healy, Wayne Mikkelson, Megan Partch, George Racette, Jim Schallheim, Dennis Sheehan, Janet Smith, René Stulz, Michael Vetsuypens, Karen Wruck, two referees and seminar participants at Arizona State University, the University of Arizona, and the University of Oregon for helpful comments on earlier drafts. The paper, previously titled "Market responses to equity private placement announcements and the pricing of privately placed equity," was presented at the American Finance Association Annual meeting, December 1990. Financial support from the Center for Financial System Research at Arizona State University is acknowledged.

${ }^{1}$ See also Kato and Schallheim (1991) on equity private placements in Japan and Fields and Mais (1991) on private placements of convertible debt.
} 
ments, and is particularly surprising in light of the sizable discounts. ${ }^{2}$ Wruck finds that changes in ownership concentration can partially explain the positive announcement effect and suggests that private placement discounts reflect compensation for expert advice or monitoring services provided by private investors. $^{3}$

In this study we develop and test the hypothesis that, in addition to ownership structure effects, private placement discounts and stock price reactions also reflect resolution of asymmetric information about firm value. We extend the Myers and Majluf (1984) model to allow the possibility that, at some cost, private placement investors can assess firm value through their negotiations with management. Our extension implies that private placements by undervalued firms can mitigate the Myers and Majluf underinvestment problem and can reduce wealth transfers to new shareholders that would result from public issues. We suggest that the willingness of private placement investors to commit funds to a firm, together with management's decision to forego public issue, conveys to the market managements' belief that the firm is undervalued. Under our extension of Myers and Majluf, private placement discounts reflect costs incurred by private investors to assess firm value and private placement announcements reveal favorable inside information about firm value.

To provide evidence on the information hypothesis we develop empirical models of the determinants of private placement discounts and stock price effects. Our analysis of discounts is based on the implication that when the value of the firm is more difficult to assess and more important to assess carefully, investors in private placements will expend more resources to determine firm value, and thus will require larger discounts. Our analysis of stock price effects is based on the implication that information effects should be larger for placements where the potential degree of undervaluation is high. Since variables we identify as proxies for the costs and benefits of assessing firm value can sometimes also proxy for the expected costs and benefits of increased monitoring, we also devise tests intended to discriminate between information and monitoring effects. These tests are based on identifying, ex ante, the private placements most likely to be associated with increased monitoring (e.g., private sales to single investors and private placements associated with material increases in ownership concentration).

Our results show that, in addition to ownership structure effects, private sales of equity have important information effects. This conclusion is based. on the results of our cross-sectional analysis of private placement discounts and stock price effects and is bolstered by descriptive evidence of heterogeneity of investor characteristics and uses of proceeds in our sample of private

\footnotetext{
${ }^{2}$ See Smith (1986) for a summary of studies of public equity issues.

${ }^{3}$ Wruck's analytical framework is based on a broad academic literature in finance and economics that focuses on the link between ownership concentration and firm value (see Jensen and Meckling (1976), Fama and Jensen (1983), Demsetz and Lehn (1985), Shleifer and Vishny (1986), Stulz (1988), and Morck, Shleifer, and Vishny (1988)).
} 
placements. The descriptive evidence indicates that while some placements have the potential to be important ownership structure events, others appear to be essentially passive investments by fairly large numbers of investors with limited ability to directly affect firm. performance. Our results, in conjunction with the findings of Wruck, are consistent with the suggestion of Morck, Shleifer, and Vishny (1988) that ownership effects are less important for smaller firms.

In Section I we develop the information hypothesis as it applies to private placements and set out the testable implications of the hypothesis for discounts and stock price reactions. We then review the ownership structure hypothesis as developed in previous literature and discuss our methods for discriminating between the two hypotheses. In Section II we describe the sample selection procedure and provide some summary information on the sample. In Section III we provide preliminary evidence useful for discriminating between the hypotheses. Results of our cross-sectional analysis are presented in Section IV. Section V concludes.

\section{Informational Asymmetry, Ownership Structure, and Equity Private Placement}

\section{A. The Information Hypothesis}

Assuming managers act in the interest of existing shareholders who are passive and that prospective investors are informationally disadvantaged about firm value, Myers and Majluf demonstrate that equity issues convey management's belief that the firm is overvalued. They show that managers of undervalued firms with profitable investment opportunities, but lacking financial slack, will choose not to issue equity whenever the share of existing assets transferred to new stockholders exceeds the share of increased firm value retained by existing stockholders. By not issuing, managers are choosing to forego the investment opportunities.

As Myers and Majluf note, this "underinvestment problem" disappears if managers can costlessly convey their private information to the market. They suggest that transactions such as mergers can mitigate the problem if managers can disclose their private information during negotiations. We hypothesize that equity private placements provide benefits similar to those suggested for mergers by Myers and Majluf. Managers with favorable information who, under the Myers and Majluf assumptions, would decline to issue publicly, may resort to private placement rather than foregoing an investment opportunity. Even if underinvestment is not a problem, we show that undervalued firms will choose private placement over public issue if doing so enables existing shareholders to retain a larger fraction of the firm.

In our extension of Myers and Majluf, we add private placement as an additional choice in the equity issue decision framework. Employing the same assumptions, timing conventions, and notation as Myers and Majluf, we assume that managers of firms lacking financial slack maximize the true (full 
information) value of the existing shareholders' claim, $V^{\text {old }}$, with respect to the choice of issuing publicly, placing equity privately or doing neither:

$$
V^{\text {old }}=\max \begin{cases}\frac{P^{\prime}}{P^{\prime}+E}(E+a+b) & \text { issue equity publicly } \\ a+b-T & \text { place equity privately } \\ a & \text { do neither }\end{cases}
$$

In equation (1) $\frac{P^{\prime}}{P^{\prime}+E}(E+a+b)$ is the value of the existing shareholders' claim if the firm issues publicly, where $P^{\prime}$ is the market value of the claim conditional on public issue, $a$ is the true value of assets in place, $b$ is the net present value of the investment opportunity and $E$ is net issue proceeds required to finance the investment. If shares are placed privately then the value of the existing shareholders' claim is $a+b-T$ where $T$ is compensation to private investors for costs they incur to determine firm value. Existing shareholders bear this cost by offering shares to private investors at a discount, $E /(E+T)$, where $E+T$ is the market value of the private investors' claim. ${ }^{4}$ If neither public issue nor private placement is chosen, the investment opportunity is foregone and the value of the existing shareholders' claim is the value of assets in place, $a$.

Private placement eliminates underinvestment if the following condition holds

$$
\frac{P^{\prime}}{P^{\prime}+E}(a+b+E)<a<a+b-T .
$$

The first inequality in (2) is the Myers and Majluf condition that underinvestment occurs when the wealth transfer to new shareholders exceeds the net present value of the investment opportunity. The second inequality is implied by our extension and shows that private placement will be employed and the project will be undertaken as long as the net present value of the investment opportunity exceeds the cost of informing private investors about firm value.

Even in the absence of an underinvestment problem, private placement results in a gain to existing shareholders if

$$
a<\frac{P^{\prime}}{P^{\prime}+E}(a+b+E)<a+b-T .
$$

The first inequality in (3) is the Myers and Majluf condition where the firm chooses to issue publicly. The second inequality shows the condition under

\footnotetext{
${ }^{4}$ Recognition that the discount reflects compensation for information costs borne by the private investors explains why placing shares at a discount can convey undervaluation. Giammarino and Lewis (1988) provide a model of public issues where the size of the discount to the underwriter reflects the issuing firm's eagerness to raise funds. In their model, larger discounts send a more favorable signal.
} 
which private placement is preferred to public issue, and can be restated as

$$
\frac{P^{\prime}}{P^{\prime}+E}<\frac{a+b-T}{a+b+E} .
$$

Thus, private placement is used rather than public issue if the proportion of ownership retained by existing shareholders under full information exceeds the proportion retained under asymmetric information.

The analysis, to this point, implies that the information conveyed by private placement is a byproduct of the decision to place shares privately rather than a result of managers' efforts to correct the market price. However, it is also possible that managers employ private placement intentionally to signal that the firm is undervalued. ${ }^{5,6}$ Among the benefits of correcting underpricing are that it benefits shareholders desiring to sell prior to revelation of the true state of nature and that it enables the firm to engage in subsequent financial transactions on more favorable terms. These kinds of benefits alter the decision framework, discussed above, such that managers may decide to issue privately even if the conditions for private placement in equations (2) or (3) are not met.

The signaling benefit raises the prospect of false signaling. If private placement signals undervaluation, overvalued firms can benefit by placing shares with investors who resell prior to revelation of the true state of nature. This would benefit existing shareholders since net proceeds from the private placement would reflect the opportunity to resell the shares at an inflated price. Rational investors recognize this incentive and will discount their estimates of value unless the signal is made credible. To credibly signal undervaluation, firms must bond against redistributions to insiders (including investors in the private placement) based on the positive stock price reaction to the announcement. Placement of unregistered stock, where resale is restricted for a period long enough to allow private information to become public, provides one such guarantee. Resale restrictions make the signal costly since private investors will require a discount to recoup resources spent to learn private information that could affect firm value over the minimum holding period. It also is possible that credibility of the signal can be enhanced by placement of a large block with a single investor at a price that reflects a control premium. In this case resale is limited since the cost of false signaling would be loss of the control premium if the shares were resold piecemeal.

\footnotetext{
${ }^{5}$ We distinguish between inadvertent and deliberate conveyance of information with reasoning analogous to Miller and Rock (1985) who make a similar distinction in the context of dividend policy. Miller and Rock initially derive the response to a dividend announcement under the assumption that managers seek to maximize firm value with respect to the dividend decision. They then derive the response when the dividend announcement is a deliberate signal and managers can benefit from a transitory increase in market value.

${ }^{6}$ The signaling mechanism is similar to those suggested in models by Leland and Pyle (1977), Campbell and Kracaw (1980), and particularly James and Wier (1990) in which investments by financial intermediaries provide information about firm value that is useful to outsiders.
} 


\section{B. Testable Implications of the Information Hypothesis}

This section sets out the testable implications of the information hypothesis. Similarities and differences in implications of the ownership structure hypothesis are addressed in Section I.C. To assist the reader, variable names appearing in the text are italicized. A summary of variable definitions is in Table I.

\section{Table I}

\section{Variable Definitions}

$\begin{aligned} & \text { Discount } \\ & \text { Discount-adjusted } \\ & \text { abnormal return }\end{aligned}$
Restricted shares
Log of proceeds
Management buyer
Single investor
Foreign investor
Institutional
investor
Financial distress

Financial distress

Speculative product

Book-to-marketequity

Fraction placed

Firm size

Ownership level

$\Delta$ Ownership

$\Delta$ Ownership $_{i}$
$=($ Price at day $+10-$ Placement price $) \div$ Price at day +10

$=\quad \mathrm{AR}_{\mathrm{adj}}=[1 /(1-\alpha)][\mathrm{AR}]+[\alpha /(1-\alpha)]\left[\left(\mathrm{P}_{\mathrm{b}}-\mathrm{P}_{0}\right) / \mathrm{P}_{\mathrm{b}}\right]$, where $\mathrm{AR}$ is the abnormal stock return, $\alpha$ is the ratio of shares placed to shares outstanding after the placement, $P_{b}$ is the market price at the end of the day prior to the event window, and $P_{o}$ is the placement price. Unless otherwise indicated AR is the four-day announcement period abnormal return $\{-3,0\}$.

$=1$ if the privately placed shares could be identified as restricted with no indication of registration rights, otherwise 0 . The latter group includes shares identified as registered and to be registered as well as shares for which registration status could not be determined.

$=\log$ of gross proceeds of the placement in dollars if available, otherwise net proceeds.

$=1$ if the buyer(s) could be identified as manager(s) or director(s), otherwise 0 .

$=1$ if it could be established that the placement was sold predominantly to one buyer, otherwise 0 .

$=1$ if the buyer(s) could be identified as foreign, otherwise 0 .

$=1$ if the buyer(s) could be identified as a financial institution, otherwise 0 .

$=1$ if the firm was facing a threat of imminent financial distress at the time of the placement as evidenced by two consecutive years of negative earnings prior to the placement, news that the company was selling assets to raise cash, or other news of imminent financial distress; otherwise 0 .

$=1$ if the firm was in the development stage of a speculative new product without significant other revenue at the time of the placement, otherwise 0 .

$=$ The ratio of book value of equity to market value of equity.

$=$ The number of shares issued as a percent of total shares outstanding after the issue.

$=$ Market value of equity 30 days prior to the private placement announcement.

$=$ Beneficial ownership of all managers and directors plus nonmanagement holdings greater than $5 \%$.

$=$ The change in ownership concentration as reported in proxy statements before and after the private sale of equity.

$=$ The $\Delta$ Ownership $_{i}$ variables $(i=1,2,3)$ split the total change in ownership into the portion moving the ownership level between 0 and $5 \%, 5$ and $25 \%$, and $25 \%$ and greater. 


\section{B.1. Implications for Private Placement Discounts}

We measure the Discount relative to share price 10 days after the private placement announcement date (day 0):

Discount $=($ Price at day $+10-$ Placement price $) \div$ Price at day +10 .

The post-announcement, "with information" price is used to measure the discount as this most accurately reflects the cost of the placement to the firm. The announcement date is the day of the first published announcement in any of our sources, or the day after the announcement appears on the broad tape.

The information hypothesis implies that when the value of the firm is more difficult to assess and more important to assess carefully, investors in private placements will expend more resources to determine firm value, and thus will require larger discounts. If investment opportunities (growth options) are more difficult to value than existing assets, it follows that discounts will be larger when placement size is large relative to firm size. Thus, we measure Fraction placed as the ratio of shares placed to shares outstanding after the issue. Similar reasoning implies larger discounts when intangible assets contribute substantially to equity market value. We employ two alternative measures of the value of intangibles. First, we use the ratio of Book-tomarket-equity as a measure of the fraction of equity market value attributable to tangible assets. We use this specification rather than the market-to-book-equity ratio, which is not well behaved in the presence of near-zero or negative book values; we have several such cases in our sample. As an alternative measure of intangibles, we use an indicator variable (Speculative product) which equals one if the firm is in the developmental stage of a speculative new product and is without significant other revenue at the time of the placement. We also expect the costs of information production to be positively related to the risk of financial distress. We use an indicator variable for Financial distress risk, which equals one if the firm experiences two consecutive years of negative earnings prior to the placement announcement, if the company is selling assets to raise cash or if other news of imminent financial distress is found.

To the extent that information production is subject to economies of scale, percentage discounts should be smaller for large placements. We use the Log of proceeds to measure placement size. Since placement size is correlated with firm size, another interpretation of a negative relation with the discount is that information asymmetries are likely to be more severe for small firms, making them more costly to evaluate and giving rise to larger discounts. Both interpretations are consistent with the information hypothesis.

The information hypothesis implies that discounts will be larger for placements where opportunistic resale of the shares is precluded. A longer required holding period provides an incentive for private placement investors to incur additional costs to assess firm prospects. Opportunistic resale is most clearly precluded by placement of unregistered or restricted shares. During 
the period of our study federal law required that restricted shares be purchased for investment purposes only. The presumption under the law was that a holding period of two years or more would comply with the legal requirement. We use an indicator variable to identify placements of $R e$ stricted shares.

We also use an indicator variable for sales to Single investors. Barclay and Holderness (1989) and Mikkelson and Regassa (1991) find evidence that prices of secondary market block transactions are higher than prices in normal exchange trading and interpret the difference as a control premium. Thus, for placements with single investors, the discount is expected to be smaller if the price reflects a control premium that partially offsets the investor's costs of becoming informed. A smaller discount for placements with single investors could also reflect information cost savings if informing multiple investors involves additional cost. As an alternative means of identifying placements of large blocks with single or small groups of investors we measure the Change in ownership concentration ( $\Delta$ Ownership) of managers, directors, and 5 percent blockholders around the placement. ${ }^{7}$ Our expectations parallel those for placements with Single investors.

The information hypothesis implies that sales to Management buyers should be associated with lower discounts since managers should incur lower (or zero) information costs. Alternatively, discounts will be larger if placement terms reflect additional compensation or managerial self-dealing. Accordingly, in the discount analysis we include Management buyers as a control variable.

\section{B.2. Implications for Information Effects}

To measure the information effects of private placement announcements we use Discount-adjusted abnormal stock returns $\left(\mathrm{AR}_{\mathrm{adj}}\right)$. As recognized by Wruck, the observed announcement effect is a measure of the information effect net of placement costs. We follow Wruck's procedure, as developed from Bradley and Wakeman (1983), and calculate the information effect as,

$$
\mathrm{AR}_{\mathrm{adj}}=[1 /(1-\alpha)][\mathrm{AR}]+[\alpha /(1-\alpha)]\left[\left(\mathrm{P}_{\mathrm{b}}-\mathrm{P}_{\mathrm{o}}\right) / \mathrm{P}_{\mathrm{b}}\right]
$$

where $\mathrm{AR}$ is the abnormal stock return, $\alpha$ is the ratio of shares placed to shares outstanding after the placement, $P_{b}$ is the market price at the end of the day prior to the event window, and $P_{o}$ is the placement price. Following Wruck, we use a four-day announcement period from day -3 to day 0 .

The information hypothesis implies that information effects should be larger for placements where the potential degree of undervaluation is high. In particular, information effects are expected to be larger when resolution of state-of-the-world risk is essentially dichotomous (e.g., a product is successful

\footnotetext{
${ }^{7}$ Each measure has advantages and disadvantages. Single investor is dichotomous and thus does not reflect the size of the placement. Change in ownership concentration is continuous and does reflect the size of the placement, but is frequently not available and is subject to measurement error if concentration changes between proxy filings for reasons other than the private placement.
} 
or not, an exploratory effort such as a mine pays off or does not, a firm in financial distress either survives or fails). Thus, we expect a more positive information effect where the firm's investment opportunities are large relative to assets in place (Fraction placed), where the value of firm equity depends largely on intangible assets (Book-to-market-equity or Speculative product) and where the firm is facing Financial distress. If, as many researchers suggest, information asymmetry (and the dichotomy of outcomes) is likely to be more severe for small firms, we expect the information effect to be negatively related to firm size. To measure Firm size we use market value of equity 30 days prior to the private placement announcement.

Costly signaling implies that credibility of the undervaluation signal depends on the identity of the investor and impediments to opportunistic resale. Thus, we expect sales to Management buyers to be viewed less positively than sales to outsiders. Our expectation is consistent with the Leland and Pyle argument that increased managerial holdings signal undervaluation. However, given the conflicting incentives of managers, we expect sales to informed outsiders to convey more positive information. Because of the reduced likelihood of opportunistic resale, we expect private placements of Restricted shares and sales at prices that partially reflect a control premium (Single investor or Change in ownership concentration) to provide more credible signals of firm value and to yield more positive information effects. ${ }^{8}$ More positive information effects are also expected for these sales if the longer expected holding period increases private investors' incentives to invest in information about firm value. Since firms can avoid issuing restricted shares via registration and because of the large discounts we find on sales of Restricted shares, we interpret a positive relationship between this variable and the discount-adjusted abnormal return as evidence of costly signaling.

\section{The Ownership Structure Hypothesis}

Private placement discounts and stock price effects may also reflect resulting changes in the ownership structure of the firm. A private placement can increase firm value by creating an outside blockholder who monitors management or contributes expert advice (Demsetz and Lehn (1985) and Shleifer and Vishny (1986)). The monitoring argument implies that private placement discounts reflect compensation to private investors for expected monitoring services and that abnormal stock returns reflect the expected benefit of increased monitoring. ${ }^{9}$ Empirical predictions are qualitatively similar to

\footnotetext{
${ }^{8}$ Placements of concentrated blocks could also be viewed positively by the market if private investors value diversification and will only take an undiversified position if positive abnormal returns are anticipated. As it turns out, however, most concentrated blocks in our sample are sold to large institutional investors and do not appear to materially affect their diversification.

${ }^{9}$ Thus, the variable $T$, which we define in Section I. $A$ as compensation to private investors for the costs they incur to determine firm value, could also reflect compensation for the expected cost of monitoring services to be provided by the private investor after the placement.
} 
those of the information hypothesis. The three variables identified previously as proxies for the costs and benefits of assessing firm value (Fraction placed, Book-to-market-equity, and Financial distress) can also proxy for the expected costs of monitoring and can imply greater benefits of increased monitoring. In addition, because of the implicit commitment to increased monitoring, sales of Restricted shares could also be associated with larger discounts and information effects.

To discriminate between information and monitoring effects we interact the Single investor indicator with the proxy variables for monitoring discussed above. The Single investor variable is intended to divide the sample into groups where monitoring is more or less likely (predominantly single versus multiple unrelated investors). To the extent that Single investor identifies placements with investors more likely to engage in monitoring, the interacted variables should be related to the discounts and discount-adjusted abnormal returns. As an alternative to Single investor, we also test interactions with the Change in ownership concentration around the private placement. Our rationale is that increased monitoring is expected to depend on the degree to which the placement results in larger increases in ownership concentration.

We also investigate the ownership structure hypothesis using a methodology, similar to Wruck (1989), that focuses on the changes in ownership concentration that take place around private sales of equity. The academic literature in finance suggests that an increase in ownership concentration can increase firm value if it aligns manager and shareholder interests, allows for more efficient monitoring of managerial performance or increases the probability of value-increasing takeovers (Jensen and Meckling (1976) and Shleifer and Vishny (1986)). Alternatively, an increase in ownership concentration can decrease firm value if it decreases the probability of takeover, or fosters misallocations of resources by entrenching management (Fama and Jensen (1983) and Stulz (1988)). As recognized by Morck, Shleifer, and Vishny (1988), the effect on firm value of an increase in ownership concentration depends on which factors dominate over a particular range of ownership concentration. Wruck finds that changes in firm value around private sales of equity are positively related to ownership changes at low and high levels of ownership, but negatively related over a middle range. Wruck concludes that while it appears that blockholders generally serve to align the interests of managers and shareholders, in some cases increased ownership concentration promotes entrenchment. We investigate whether a similar finding obtains for our sample of private placements.

\section{Data and Methodology}

\section{A. Identification of the Sample}

We use a sample of announcements from January 1, 1980 through May 31, 1987. The initial sample was identified by searching for public announce- 
ments of equity private placements in the Dow Jones News Retrieval Service, Standard and Poor's News Reports, and Investment Dealers' Digest. We also examined S\&P Stock Reports, Moody's Manuals and Q-files for prospectuses and 10 -Ks containing information related to the private placements. Observations were retained only if we found no indication that other securities were sold at the same time, and only if sufficient information about placement terms was available from our sources. Observations where the price of privately placed shares could not be determined were excluded. Firms with insufficient stock returns data reported on the CRSP or NASDAQ tape were also deleted. Finally, we excluded all observations where there was evidence of leakage or where the announcement date could not be identified. ${ }^{10}$ This procedure resulted in a sample of 106 private placement announcements. The majority ( 75 percent) are for OTC firms. ${ }^{11}$ Two-thirds of the placements occurred during the last half of the period of study. ${ }^{12}$

\section{B. Sample Description}

Table II provides summary information for our sample (Panel A) and comparison information for a sample of firm-commitment public equity issues for the same period (Panel B). Panel A shows average proceeds of $\$ 11.4$ million for our private placement sample. The average equity market value is $\$ 94.7$ million. $^{13}$ In contrast to public issues, firms in our sample that place equity privately tend to be much smaller and to seek much smaller amounts of new equity.

The costs of public issues and private placements can be contrasted by comparing private placement discounts with the underwriter spread and other costs for public issues. By placing privately, an undervalued seller avoids the negative public issue announcement effect, the underwriter spread, residual underpricing, and other issue costs not reflected in the spread. Since firms choosing private placement differ markedly from those choosing public issue, simple cost comparisons can be misleading. Still, figures in Table II suggest that firms choosing private placement face higher costs than those choosing public issue. In part, the difference in cost reflects the difference in

\footnotetext{
${ }^{10}$ In 40 cases announcements referred to earlier press releases for which we did not find published reports or there were "anticipatory" announcements suggesting the possibility of a placement. Results for the larger sample that includes this subset of placements are also discussed in the paper.

${ }^{11}$ Our sample of placements by exchange-listed firms is smaller than that used by Wruck. We believe the primary difference is that our on-line searches included fewer synonyms for "private placement" and also screened out announcements where other types of securities such as "debt" were mentioned and announcements including other news of types known to be associated with stock price reactions. Our additional screens also appear to be somewhat more restrictive than those used by Wruck.

${ }^{12} \mathrm{~A}$ statistical appendix is available from the authors on request. The appendix includes a detailed breakdown of the time and listing distributions of the sample, as well as information on other relationships discussed in the paper.

${ }^{13}$ These compare to average proceeds of $\$ 31.5$ million and an average equity market value of $\$ 233.7$ million reported by Wruck for her sample of placements by listed firms.
} 


\section{Table II \\ Sample Characteristics of Equity Private Placements Compared to Public Issues}

The private placement sample includes 106 placements by NYSE, AMEX, and OTC firms between $1 / 1 / 80$ and 5/31/87. Market value of equity is from the CRSP tapes and is measured 30 days prior to the private placement announcement. The discount is measured relative to share price 10 days after the announcement. The public issue sample includes firm-commitment offers of seasoned securities reported on the SEC Registered Offering Statistics tape from 1980 to 1987 where the issue was not combined with issuance of other securities and where stock returns data were reported on the CRSP or NASDAQ tape around the issue date.

\begin{tabular}{lccc}
\hline & Mean & Median & Number \\
\hline & Panel A: Private Placements & \\
\hline Proceeds (millions) & $\$ 11.38$ & $\$ 5.40$ & 106 \\
Market value of equity (millions) & $\$ 94.68$ & $\$ 45.93$ & 106 \\
Fraction placed & $15.98 \%$ & $13.26 \%$ & 106 \\
Discount (percent of market price) & $20.14 \%$ & $13.25 \%$ & 106 \\
\hline \multicolumn{3}{c}{ Panel B: Public Issues } & \\
\hline Proceeds (millions) & $\$ 38.98$ & $\$ 20.86$ & 2560 \\
Market value of equity (millions) & $\$ 441.45$ & $\$ 116.14$ & 2424 \\
Fraction placed & $16.52 \%$ & $14.55 \%$ & 2424 \\
Underwriter spread (percent of proceeds) & $5.29 \%$ & $5.24 \%$ & 2560 \\
\hline
\end{tabular}

\footnotetext{
a In 99 cases gross proceeds are reported, in four cases net proceeds are reported, and in three cases we were unable to determine whether the proceeds reported were net or gross.
}

size of private placements and public issues. The average underwriter spread for public issues in the $\$ 5$ to $\$ 10$ million range (similar to the private placement sizes in our sample) is 7.4 percent. Other factors also suggest higher costs for firms placing privately. For example, firms with high financial distress risk appear to be more likely to raise funds by private placement. ${ }^{14}$

Private placement discounts in our sample vary widely. Thirty-nine of the placements in our sample were made at discounts of more than 25 percent and 8 were at premiums of more than 10 percent. Premiums appear to reflect the value of control, cash infusions by investors who already own much of the outstanding stock, and market price declines between the time the placement price is negotiated and when it is announced to the market. ${ }^{15}$ Discounts appear to be related to such factors as resale restrictions, placement size, and

\footnotetext{
${ }^{14}$ Several of the firms in our private placement sample had negative book equity around the time of the placement. Twenty-one of the firms experienced at least two years of negative earnings or other significant news concerning financial distress risk around the time of the placement.

${ }^{15}$ Six of the 8 placements that were sold at premia greater than 10 percent declined substantially in price from day -30 to day +10 (15.1 percent average decline) and 6 were purchases by single investors, 2 of which were purchases by related companies with substantial ownership interests prior to the transaction.
} 
type of investor. For 18 placements in our sample there is explicit recognition that the privately placed shares were unregistered and therefore subject to resale restrictions. Conversely, 45 were identified either as registered shares or sold with registration pending. Placements by listed firms, placements sold to foreign investors, and placements sold to corporate and institutional investors tend to be larger than average, whereas placements of restricted shares are smaller. ${ }^{16}$ Sales to corporations and management and sales of restricted shares all involve relatively large percentage increases in outstanding shares.

Table III reports average cumulative abnormal returns for issuing firms around private placement announcements. Abnormal returns are measured using a market model where, because of the small firms in our sample, we estimate beta using the Scholes-Williams (1977) method. ${ }^{17}$ The average four-day announcement period abnormal return is 1.72 percent and statistically significant. While this increase is smaller than reported by Wruck, we suspect the difference is due primarily to the additional difficulty we encountered in identifying announcement dates for the smaller firms included in our sample. For a window extending from day -29 to day +10 (which our testing suggests captures most of the potential leakage) we find a significant abnormal return of almost 9 percent. ${ }^{18}$ Since results of the cross-sectional analysis are similar for the $\{-3,0\}$ and the $\{-29,10\}$ windows, we report only those using the conventional window.

We also examined stock price performance over a longer period prior to the private placement. Studies of public issues generally report positive abnormal returns of around 30 percent over the 500 days prior to public issue announcements. Lucas and McDonald (1990) summarize this evidence and develop a model that attributes the price rise to informational asymmetry. In their model, both the run-up and the negative issue announcement effect derive from the decision of managers of undervalued firms to postpone equity issues until they believe the stock is no longer undervalued. In contrast, if private placements are used to resolve the informational asymmetry or to improve ownership structure, a prolonged period of positive abnormal returns should not be observed for firms electing private placement. Over the interval beginning 500 days prior and ending 30 days prior to the private placement announcement $\{-500,-30\}$ the average cumulative abnormal return for firms in our sample is $-\mathbf{1 4 . 8}$ percent and is significant at the 10 percent level. ${ }^{19}$ In the context of Lucas and McDonald this result suggests that, for

\footnotetext{
${ }^{16}$ Foreign investors are significantly less likely to have invested in firms engaged in speculative product development or facing financial distress or to purchase unregistered shares.

${ }^{17}$ See Dodd and Warner (1983) for description of event study procedures and statistical tests.

${ }^{18}$ To evaluate whether positive returns before the announcement reflect leakage we examined the timing of returns for an expanded sample that includes 40 observations where leakage could be documented. While total abnormal returns are similar for both groups, the timing of returns between the full and expanded samples is consistent with the leakage explanation.

${ }^{19}$ This result is based on a subsample of 83 firms with sufficient returns data available over the interval.
} 
Table III

\section{Cumulative Abnormal Returns around Announcements of Equity Private Placements}

Cumulative abnormal returns (CAR) are calculated using a market model with beta estimated using the Scholes-Williams (1977) technique. The \% positive is the percent of the sample with positive cumulative abnormal returns. The sample includes 106 private placements between $1 / 1 / 80$ and $5 / 31 / 87$.

\begin{tabular}{lcccccc}
\hline & \multicolumn{7}{c}{ Period Relative to the Announcement Date (Day 0) } \\
\cline { 2 - 7 } Statistics & $\{-59,-30\}$ & $\{-29,-10\}$ & $\{-9,0\}$ & $\{-3,0\}$ & $\{1,10\}$ & $\{-29,10\}$ \\
\hline Mean CAR & 1.23 & $4.99^{\mathrm{a}}$ & $3.28^{\mathrm{b}}$ & $1.72^{\mathrm{b}}$ & 0.51 & $8.78^{\mathrm{a}}$ \\
$(Z)$ & $(0.92)$ & $(3.22)$ & $(2.48)$ & $(2.30)$ & $(0.86)$ & $(3.95)$ \\
\% positive & 48.1 & $60.4^{\mathrm{b}}$ & $64.2^{\mathrm{a}}$ & $58.8^{\mathrm{c}}$ & 47.2 & $64.2^{\mathrm{a}}$ \\
\hline
\end{tabular}

a, b, $c$ denote significance (using a two-tailed test) at the $1 \%, 5 \%$, and $10 \%$ levels, respectively.

undervalued firms, equity private placement is a substitute for delaying public issue. Alternatively, the negative returns prior to day -30 could reflect the benefit of an improved ownership structure.

\section{Preliminary Evidence}

\section{A. Descriptive Evidence}

This section presents descriptive evidence on the uses of private placement proceeds, investor characteristics, and changes in ownership structure. The evidence supports our conclusion that in addition to ownership structure effects, private placements have an important information dimension.

We examine the stated use of proceeds, since the information hypothesis is based on the premise that proceeds are used to fund new investment rather than used narrowly for capital restructuring. Information on use of proceeds was reported for 64 of the firms in our sample. Indications that proceeds would be invested in corporate assets were provided for 44 firms, compared to 13 firms with references to capital restructuring. ${ }^{20}$ Seven of these firms indicated both investment and capital restructuring reasons for the placements. On balance, this evidence suggests that the asset investment aspect of the placement is a contributing factor to the discount and the stock price reaction.

Table IV contains information on the characteristics and numbers of investors involved in the private placements in our sample. Panel A reports that 35 placements were identified as sold to foreign investors and 53 as sold

\footnotetext{
${ }^{20}$ Investment reasons included expansion, growth or capital equipment (23 placements), working capital (15 placements), acquisitions (5 placements), research and development (3 placements), joint venture ( 1 placement) and subsidiary capital ( 2 placements). The only restructuring reason given was debt reduction (13 placements). General corporate purposes was the reason given for 15 placements. No reason could be identified for 42 placements.
} 


\section{Table IV}

\section{Characteristics and Numbers of Private Placement Investors}

This table reports descriptive information on investor characteristics and the numbers of investors in private placements. The sample includes 106 equity private placements between $1 / 1 / 80$ and $5 / 31 / 87$.

\begin{tabular}{lc}
\hline & Panel A: Characteristics of Private Placement Investors \\
\hline Characteristics & Frequency $^{\mathrm{a}}$ \\
\hline Foreign investors & 35 \\
Institutions & 53 \\
Other corporations & 7 \\
Management & 6 \\
\hline & Panel B: Numbers of Private Placement Investors \\
\hline Number of Investors & Frequency \\
\hline Single investor & 30 \\
Multiple investors & 57 \\
More than 30 & 6 \\
15-29 & 7 \\
5-14 & 3 \\
$2-4$ & 6 \\
"Multiple" & 35 \\
Number of investors not specified & 19 \\
\hline \multicolumn{1}{c}{ Panel C: Characteristics of Identified Investors (23 Placements) } \\
\hline Characteristics & Frequency \\
\hline Individual & 3 \\
Foreign institution & 4 \\
Life insurance company & 6 \\
Bank & 3 \\
Corporation & 6 \\
Investment fund & 4 \\
\hline
\end{tabular}

a Except for "foreign investors" the classifications are mutually exclusive.

${ }^{b}$ Classifications are not mutually exclusive.

to institutions. Panel B shows that only 30 placements were reported as sold predominantly to a single buyer; 13 placements were reported to have been made to 15 or more unrelated investors; and 35 explicitly indicated that "multiple" investors were involved but did not state a number. Panel C reports information for the subset of sales to single investors where the identity of the investor was disclosed. Most of those investors were large domestic or foreign financial institutions including banks, life insurance companies, or investment funds.

It is apparent from Table IV that some placements in the sample are more likely to be important ownership structure events whereas others appear to be essentially passive investments by fairly large numbers of investors with limited abilities to affect firm performance directly. Whereas 28 percent of 
our observations were sold to single investors and a substantial fraction were sold to fairly large numbers of unrelated investors, Wruck reports 58 percent sold to single investors and very few placements to more than six investors. The foreign placements in our sample appear to be mainly passive investments: of the 35 placements identified as sold to foreign investors only 6 were blocks placed with single investors. We also found that of the 30 placements with foreign institutions, only three were sales to a single buyer. This stands in sharp contrast with sales to domestic institutions where 16 out of 23 were placed with a single institution.

Additional evidence of the effects of equity private placement on ownership concentration is presented in Table $\mathrm{V}$ for a subsample of 70 placements where the necessary data are available. Total holdings by managers, directors, and

\section{Table V \\ Ownership Concentration of Firms Making Equity Private Placements}

This table reports mean ownership concentration of firms making private placements as reported in proxy statements before and after the sale. The proxy statements report beneficial ownership of all managers and directors, and nonmanagement holdings greater than 5 percent. The mean change in holdings is the average of (percent holdings before - percent holdings after). The $p$-values are from the Wilcoxon signed-rank test of the hypothesis that the change in holdings (or difference between groups) is not different from zero. All calculations are based on undiluted holdings. The sample includes 70 private placements between $1 / 1 / 80$ and $5 / 31 / 87$ where ownership data before and after the placement were reported.

\begin{tabular}{|c|c|c|c|c|c|}
\hline & $\begin{array}{c}\text { Percent } \\
\text { Holdings } \\
\text { Before }\end{array}$ & $\begin{array}{l}\text { Percent } \\
\text { Holdings } \\
\text { After }\end{array}$ & $\begin{array}{l}\text { Change in } \\
\text { Holdings }\end{array}$ & $\begin{array}{l}p \text {-Value for } \\
\text { Change in } \\
\text { Holdings }\end{array}$ & $N$ \\
\hline \multicolumn{6}{|c|}{ Panel A: Total, Management, and Nonmanagement Holdings } \\
\hline Total holdings & 30.3 & 31.2 & 1.0 & 0.50 & 70 \\
\hline Manager and director holdings & 21.9 & 20.4 & -1.5 & 0.00 & 70 \\
\hline Nonmanagement holdings & 8.3 & 10.8 & 2.4 & 0.11 & 70 \\
\hline \multicolumn{6}{|c|}{ Panel B: Total Holdings for Various Subsamples ${ }^{a}$} \\
\hline Single investor & 33.1 & 36.7 & 3.7 & 0.21 & 20 \\
\hline $\begin{array}{l}\text { Other } \\
p \text {-Value for difference }\end{array}$ & 29.2 & 29.0 & $\begin{array}{l}-0.1 \\
(0.05)\end{array}$ & 0.16 & 50 \\
\hline Institutional investor & 27.4 & 25.7 & -1.7 & 0.07 & 36 \\
\hline $\begin{array}{l}\text { Other } \\
\quad p \text {-Value for difference }\end{array}$ & 33.3 & 37.1 & $\begin{array}{c}3.8 \\
(0.29)\end{array}$ & 0.46 & 34 \\
\hline Foreign investor & 23.1 & 21.5 & -1.6 & 0.12 & 24 \\
\hline $\begin{array}{l}\text { Other } \\
p \text {-Value for difference }\end{array}$ & 34.0 & 36.3 & $\begin{array}{c}2.3 \\
(0.14)\end{array}$ & 0.70 & 46 \\
\hline Foreign institution & 23.5 & 21.0 & -2.5 & 0.06 & 20 \\
\hline $\begin{array}{l}\text { Domestic institution } \\
p \text {-Value for difference }\end{array}$ & 32.2 & 31.5 & $\begin{array}{l}-0.8 \\
(0.15)\end{array}$ & 0.75 & 16 \\
\hline
\end{tabular}

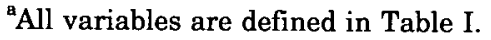


5 percent or greater outside blockholders averages 30.3 percent prior to the private equity sale and 31.2 percent after. The average change in total holdings is 1.0 percent and not significantly different from zero. We find a small decrease in manager and director holdings and a small increase in outside blockholder ownership. Our findings contrast with those of Wruck, who finds lower initial holdings by managers and a significant shift to more concentrated holdings suggesting that ownership structure effects are less important for our sample. ${ }^{21}$

The table also contains information on ownership concentration changes for subsets of the data and tests for differences between the subsets. Consistent with the view that placements with single investors are more likely to be important ownership structure changes, we find that sales to single investors are associated with an increase in ownership concentration of 3.7 percent; the multiple investor group shows essentially no change in ownership concentration. Concentration levels increase for placements with noninstitutional buyers and placements with domestic buyers. Concentration levels decrease for placements with institutional buyers and foreign buyers. The largest average decrease is found for the subsample of 20 foreign institutional buyers. ${ }^{22}$ Throughout the table, concentration increases are associated with firms having high initial ownership concentration levels. While significance levels are marginal, the overall pattern is consistent with the view that domestic and noninstitutional placements may be important ownership structure events leading to increased monitoring, managerial entrenchment, or incentive alignment.

To provide further descriptive evidence on the ownership structure hypothesis, we examined changes in board composition around private placements sold through identified agents or where the private investor was identified. We examined placements done through agents to help determine whether the agent became actively involved in management or monitoring of the firm. We considered that private placements through agents might be important ownership structure events even though ownership concentration did not increase. Board composition data were available for 31 placements through agents. We found no cases where the agent joined the board after the placement. In contrast, we found that of the 23 placements to single investors where the buyer was identified, four of the buyers went on the board after the placement. These findings suggest that the measures of changes in ownership concentration used in our analysis are related to the potential for ownership structure to be affected by the placement. Placements with named single investors are more likely to be associated with these kinds of board membership changes than placements to multiple investors done through agents. However, even single investors rarely join the board of directors around the

\footnotetext{
${ }^{21}$ Initial holdings of managers in our sample average 21.9 percent compared to 13.1 percent for Wruck.

${ }^{22}$ Decreases in measured ownership concentration result if a placement increases the number of shares outstanding without proportionally increasing shares owned by management or 5 percent blockholders.
} 
time of a private placement. To the limited extent that board membership is related to the importance of an ownership structure change, this evidence weighs against the ownership structure hypothesis for many of the placements in our sample. ${ }^{23}$

\section{B. Discounts and Discount-Adjusted Abnormal Returns: Bivariate Relations}

Table VI reports descriptive evidence on the bivariate relations between the discounts and discount-adjusted returns and the independent variables used in our cross-sectional analysis. Panel A contains results for the continuous independent variables. Based on Spearman correlation tests, private placement discounts and discount-adjusted abnormal returns are significantly related to each of the variables in the table except for the ownership concentration measures. We find larger discounts and discount-adjusted abnormal returns for small placements, placements by small firms, placements where the fraction placed is large, and placements where the value of intangible assets is an important component of firm value. Average discounts are quite large for small placements and placements where Book-to-marketequity ratios are low. Discounts approach zero for large placements and placements where Book-to-market-equity ratios are high. For no group is there a premium on average. Except in two cases, positive average information effects are found for all data groupings. None of the bivariate relations between Ownership concentration or Change in ownership concentration and discounts or discount-adjusted abnormal returns is statistically significant. ${ }^{24}$

Panel B contains results for the indicator variables. We find significantly larger discounts for shares placed by firms facing Financial distrèss, shares

\footnotetext{
${ }^{23}$ The approach of examining board composition does not preclude the possibility of increased monitoring by a private investor who is not a board member. To gain further insight we have contacted several of the private investors named in our sample and have contacted investment bankers and others who are active in the private placement market. While it is risky to generalize about such conversations, the common response we received is that private placement investors sometimes do perform a monitoring function but frequently do not. Some of the people we spoke with indicated that financial institutions were probably less likely to monitor than were other corporations. One representative of a life insurance company indicated that the firm did not seek a monitoring or managerial role in its investments but might ultimately be forced to take on such a role if the firm were faced with financial distress.

${ }^{24}$ Average discounts and discount-adjusted abnormal returns grouped by issuing firm stock price 30 days before the announcement were also examined. While we found no relation between stock prices and discount-adjusted abnormal returns, a negative relation between stock prices and discounts was significant, suggesting that information costs facing private investors are higher for firms with low-priced shares. A possible explanation is that share price is endogenously determined by other variables that are related to the discount. To explore this issue we partitioned the data set based on stock price at day -30 and found that firms with share prices below five dollars were significantly different from others in several respects. First, placement sizes were significantly smaller for such firms. Second, firms with low-priced shares were more likely to be classified as facing financial distress or to be engaged in development of speculative products. The relation between discount and stock price appears to be determined primarily by these factors.
} 
placed by firms engaged in Speculative product development and placements of Restricted shares. Discounts are significantly smaller for shares placed with Single investors and placements with Foreign investors. Discounts for placements with Management buyers are not significantly different from discounts for those placed with others. Discount-adjusted abnormal returns are significantly more positive for Restricted shares and shares placed by firms facing Financial distress and significantly smaller for placements with Single investors and placements with Foreign investors. Other relationships are not significant. The mean values of the discount-adjusted abnormal returns are positive for all groupings.

Since a number of the variables in Table VI are correlated with each other, the bivariate relations to discounts and discount-adjusted abnormal returns are only suggestive. However, some observations are worth noting. First, the lack of a significant relationship between Change in ownership concentration and discount-adjusted returns indicates that there is not a strong monotonic relationship between this measure of ownership structure change and the change in firm value associated with equity private placements. This does not preclude a weaker relationship or a more complex relationship such as that documented by Morck, Shleifer, and Vishny and Wruck. Second, the fact that the discount-adjusted return is significantly lower for placements with Single investors than for other placements weighs against the variant of the ownership structure hypothesis which holds that the gain arises from creating a large blockholder who will act as a monitor. Finally, evidence of significantly lower discount-adjusted abnormal returns for placements with foreign investors appears to provide some support for the monitoring explanation. Since foreign investors are likely to find monitoring more costly, a more positive stock price reaction for domestic placements suggests that monitoring may be important. We examine these issues more fully in the remainder of the paper.

\section{Cross-Sectional Results}

\section{A. Cross-Sectional Tests of the Information Hypothesis}

Cross-sectional regression tests of the information hypothesis are reported in Tables VII and VIII. Table VII contains the ordinary least squares analysis of private placement discounts. Significance levels are computed using the White (1980) correction for heteroskedasticity. Consistent with our prediction that private placement discounts reflect information costs borne by private investors, we find larger discounts for placements by firms that are difficult to value and where the degree of uncertainty about firm value is high. The positive and highly significant coefficient on Fraction placed is consistent with the joint hypothesis that discounts reflect information costs and that investment opportunities are more difficult to value than assets in place. The coefficient on Financial distress is positive and marginally significant and suggests that investors in firms facing financial distress require, on average, an additional discount of about 9 percent. The coefficient on Book-to-market- 
equity indicates that where intangible assets are an important component of firm value, private placement discounts are significantly higher. These findings all suggest private investors incur higher costs when assessing the future prospects of firms that are difficult to value and when the degree of uncertainty about firm value is high. As an alternative specification, we estimated the model substituting Speculative product for Book-to-market-

\section{Table VI}

\section{Descriptive Information on Private Placement Discounts and Discount-Adjusted Abnormal Returns}

Discounts are measured relative to share price 10 days after the announcement. Discount-adjusted abnormal returns are measured over the interval from 3 days before to the day of the announcement. The sample includes 106 private placements between 1/1/80 and 5/31/87. Because of unavailability of data there are 70 observations for the ownership concentration variables. All variables are defined in Table I.

\begin{tabular}{|c|c|c|c|c|c|c|}
\hline & \multirow[b]{2}{*}{$\begin{array}{c}\text { Range of } \\
\text { Values }\end{array}$} & \multicolumn{2}{|c|}{ Discount (\%) } & \multicolumn{2}{|c|}{$\begin{array}{c}\text { Discount-Adjusted } \\
\text { Abnormal Return (\%) }\end{array}$} & \multirow[b]{2}{*}{$\begin{array}{l}\text { Number of } \\
\text { Observations }\end{array}$} \\
\hline & & Mean & $p$-Value ${ }^{\mathrm{d}}$ & Mean & $p$-Value ${ }^{d}$ & \\
\hline \multicolumn{7}{|c|}{ Panel A: Continuous Variables } \\
\hline $\begin{array}{l}\text { Market value } \\
\text { of equity } \\
\text { (millions) }\end{array}$ & $\begin{array}{l}\leq \$ 10.0 \\
10.0-25.0 \\
25.0-75.0 \\
75.0-100.0 \\
>100.0\end{array}$ & $\begin{array}{c}34.6^{\mathrm{a}} \\
35.6^{\mathrm{a}} \\
17.2^{\mathrm{a}} \\
3.4 \\
8.7^{\mathrm{b}}\end{array}$ & 0.00 & $\begin{array}{c}22.4^{\mathrm{a}} \\
13.1^{\mathrm{a}} \\
6.6^{\mathrm{a}} \\
0.3 \\
1.7\end{array}$ & 0.00 & $\begin{array}{r}13 \\
24 \\
32 \\
8 \\
29\end{array}$ \\
\hline Fraction placed & $\begin{array}{l}\leq 5.0 \% \\
5.0-10.0 \\
10.0-15.0 \\
15.0-20.0 \\
>20.0\end{array}$ & $\begin{array}{l}10.7^{\mathrm{c}} \\
20.9^{\mathrm{a}} \\
19.0^{\mathrm{a}} \\
13.1^{\mathrm{c}} \\
30.8^{\mathrm{a}}\end{array}$ & 0.02 & $\begin{array}{c}0.9 \\
3.3^{\mathrm{c}} \\
5.5^{\mathrm{b}} \\
3.4 \\
22.4^{\mathrm{a}}\end{array}$ & 0.00 & $\begin{array}{l}15 \\
23 \\
24 \\
18 \\
26\end{array}$ \\
\hline $\begin{array}{l}\text { Book-to-market- } \\
\text { equity ratio }\end{array}$ & $\begin{array}{l}\leq 0.1 \\
0.1-0.4 \\
0.4-0.7 \\
0.7-1.0 \\
>1.0\end{array}$ & $\begin{array}{c}31.3^{\mathrm{a}} \\
25.0^{\mathrm{a}} \\
21.9^{\mathrm{a}} \\
5.0 \\
3.3\end{array}$ & 0.00 & $\begin{array}{c}12.8^{\mathrm{a}} \\
11.5^{\mathrm{a}} \\
8.4^{\mathrm{a}} \\
-0.4 \\
2.0\end{array}$ & 0.04 & $\begin{array}{l}25 \\
29 \\
23 \\
16 \\
13\end{array}$ \\
\hline $\begin{array}{l}\text { Proceeds } \\
\text { (millions) }\end{array}$ & $\begin{array}{l}\leq \$ 1.0 \\
1.0-5.0 \\
5.0-10.0 \\
10.0-20.0 \\
>20.0\end{array}$ & $\begin{array}{c}43.7^{\mathrm{b}} \\
33.1^{\mathrm{a}} \\
15.1^{\mathrm{a}} \\
10.1^{\mathrm{b}} \\
0.2\end{array}$ & 0.00 & $\begin{array}{l}14.1 \\
15.2^{\mathrm{a}} \\
2.2 \\
3.7^{\mathrm{b}} \\
2.3\end{array}$ & 0.01 & $\begin{array}{r}6 \\
41 \\
21 \\
19 \\
19\end{array}$ \\
\hline $\begin{array}{l}\text { Ownership } \\
\text { concentration }\end{array}$ & $\begin{array}{l}<5.0 \% \\
5.0-25.0 \\
>25.0\end{array}$ & $\begin{array}{r}5.7^{\mathrm{b}} \\
24.2^{\mathrm{a}} \\
16.8^{\mathrm{a}}\end{array}$ & 0.40 & $\begin{array}{r}-1.1 \\
7.9^{b} \\
5.3^{b}\end{array}$ & 0.18 & $\begin{array}{r}9 \\
26 \\
35\end{array}$ \\
\hline $\begin{array}{l}\text { Change in } \\
\text { ownership } \\
\text { concentration }\end{array}$ & $\begin{array}{l}<(5.0 \%) \\
(5.0)-0.0 \\
0.0-5.0 \\
>5.0\end{array}$ & $\begin{array}{c}20.1^{\mathrm{a}} \\
20.0^{\mathrm{a}} \\
6.0^{0} \\
21.5^{\mathrm{b}}\end{array}$ & 0.28 & $\begin{array}{l}4.7^{\mathrm{c}} \\
5.2^{\mathrm{c}} \\
4.5 \\
7.3^{\mathrm{c}}\end{array}$ & 0.88 & $\begin{array}{l}21 \\
20 \\
12 \\
17\end{array}$ \\
\hline
\end{tabular}


Table VI-Continued

\begin{tabular}{|c|c|c|c|c|c|c|}
\hline & \multirow[b]{2}{*}{$\begin{array}{c}\text { Range of } \\
\text { Values }\end{array}$} & \multicolumn{2}{|c|}{ Discount (\%) } & \multicolumn{2}{|c|}{$\begin{array}{c}\text { Discount-Adjusted } \\
\text { Abnormal Return (\%) }\end{array}$} & \multirow[b]{2}{*}{$\begin{array}{l}\text { Number of } \\
\text { Observations }\end{array}$} \\
\hline & & Mean & $p$-Value ${ }^{\mathrm{d}}$ & Mean & $p$-Value ${ }^{d}$ & \\
\hline \multicolumn{7}{|c|}{ Panel B: Indicator Variables } \\
\hline $\begin{array}{l}\text { Financial distress } \\
\text { Other }\end{array}$ & & $\begin{array}{l}34.8^{\mathrm{a}} \\
16.5^{\mathrm{a}}\end{array}$ & 0.01 & $\begin{array}{r}18.7^{\mathrm{a}} \\
5.6^{\mathrm{a}}\end{array}$ & 0.01 & $\begin{array}{l}21 \\
85\end{array}$ \\
\hline $\begin{array}{l}\text { Speculative product } \\
\text { Other }\end{array}$ & & $\begin{array}{l}32.2^{\mathrm{a}} \\
14.7^{\mathrm{a}}\end{array}$ & 0.00 & $\begin{array}{r}11.3^{\mathrm{a}} \\
6.8^{\mathrm{a}}\end{array}$ & 0.25 & $\begin{array}{l}33 \\
73\end{array}$ \\
\hline $\begin{array}{l}\text { Single investor } \\
\text { Other }\end{array}$ & & $\begin{array}{l}11.7^{\mathrm{b}} \\
23.3^{\mathrm{a}}\end{array}$ & 0.06 & $\begin{array}{l}4.3^{\mathrm{c}} \\
9.7^{\mathrm{a}}\end{array}$ & 0.09 & $\begin{array}{l}30 \\
76\end{array}$ \\
\hline $\begin{array}{l}\text { Restricted shares } \\
\text { Other }\end{array}$ & & $\begin{array}{l}42.0^{\mathrm{a}} \\
15.6^{\mathrm{a}}\end{array}$ & 0.00 & $\begin{array}{c}19.8^{\mathrm{a}} \\
5.8\end{array}$ & 0.03 & $\begin{array}{l}18 \\
88\end{array}$ \\
\hline $\begin{array}{l}\text { Management buyer } \\
\text { Other }\end{array}$ & & $\begin{array}{l}44.3^{\mathrm{b}} \\
18.7^{\mathrm{a}}\end{array}$ & 0.20 & $\begin{array}{r}23.5^{\mathrm{c}} \\
7.3^{\mathrm{a}}\end{array}$ & 0.22 & $\begin{array}{c}6 \\
100\end{array}$ \\
\hline $\begin{array}{l}\text { Foreign investor } \\
\text { Other }\end{array}$ & & $\begin{array}{r}9.8^{\mathrm{b}} \\
25.2^{\mathrm{a}}\end{array}$ & 0.01 & $\begin{array}{c}1.1 \\
11.7^{\mathrm{a}}\end{array}$ & 0.01 & $\begin{array}{l}35 \\
71\end{array}$ \\
\hline Full sample & & $20.1^{\mathrm{a}}$ & & $8.2^{\mathrm{a}}$ & & 106 \\
\hline
\end{tabular}

$a, b, c$ denote that the average is significantly different from zero (using a two-tailed test) at the $1 \%, 5 \%$, and $10 \%$ levels, respectively.

${ }^{d}$ The $p$-values in Panel A are based on Spearman rank correlation tests that use individual observations. The $p$-values in Panel B are for two-tailed difference in means tests for differences between subsamples.

\section{Table VII}

\section{Cross-Sectional Regression of Private Placement Discounts}

The dependent variable is the private placement discount measured relative to share price 10 days after the announcement. The $p$-values are based on White-corrected standard errors. The sample includes 106 private placements between $1 / 1 / 80$ and $5 / 31 / 87$.

\begin{tabular}{lccc}
\hline Independent Variables $^{\mathrm{a}}$ & Predicted Sign & Coefficient & $p$-Value \\
\hline Intercept & & 1.402 & 0.00 \\
Fraction placed & $(+)$ & 0.410 & 0.02 \\
Financial distress & $(+)$ & 0.091 & 0.12 \\
Book-to-market-equity & $(-)$ & -0.141 & 0.02 \\
Log of proceeds & $(-)$ & -0.078 & 0.00 \\
Restricted shares & $(+)$ & 0.135 & 0.00 \\
Single investor & & -0.091 & 0.06 \\
Management buyer & & 0.021 & 0.43 \\
$F$-value & & 11.55 & 0.00 \\
Adjusted $R^{2}$ & & $41.3 \%$ & \\
\hline
\end{tabular}

\footnotetext{
${ }^{\text {a} A l l ~ v a r i a b l e s ~ a r e ~ d e f i n e d ~ i n ~ T a b l e ~} \mathrm{I}$.
} 
Table VIII

\section{Weighted Least Squares Regression of Discount-Adjusted} Abnormal Returns

The dependent variable is the discount-adjusted return over the interval from 3 days before to the day of the announcement. Observations are weighted by the reciprocal of the residual variance obtained from estimating the market model. The sample includes 106 private placements between $1 / 1 / 80$ and $5 / 31 / 87$.

\begin{tabular}{lccc}
\hline Independent Variables $^{\mathrm{a}}$ & Predicted Sigrı & Coefficient & $p$-Value \\
\hline Intercept & & 0.072 & 0.67 \\
Fraction placed & $(+)$ & 0.628 & 0.00 \\
Financial distress & $(+)$ & 0.037 & 0.25 \\
Firm size & $(-)$ & -0.003 & 0.69 \\
Book-to-market-equity & $(-)$ & -0.079 & 0.00 \\
Restricted shares & $(+)$ & 0.078 & 0.07 \\
Single investor & $(+)$ & -0.020 & 0.32 \\
Management buyer & $(-)$ & -0.032 & 0.53 \\
$F$-value & & 15.02 & 0.00 \\
Adjusted $R^{2}$ & & $48.3 \%$ & \\
\hline
\end{tabular}

${ }^{a}$ All variables are defined in Table $\mathbf{I}$.

equity. The coefficient on Speculative product was 13 percent and highly significant. The alternative specification also yielded a larger and more significant coefficient on Financial distress. The other relationships in the model were not substantially affected.

The coefficient on the Log of proceeds is negative and significant implying smaller discounts for large placements. This finding is consistent with our prediction that discounts reflect scale economies in information production and with the view that asymmetry of information is greater for small firms.

We find an additional discount of 13.5 percent for placements of Restricted shares. This finding is consistent with the view that restricting resale is costly for the firm. An alternative explanation is that this additional discount reflects the illiquidity of restricted shares even if information costs are not higher than for other shares. While this interpretation is also consistent with costly signaling, we think it unlikely that a pure illiquidity effect can explain the magnitude of the discounts we find..$^{25}$

Sales to Single investors are associated with significantly smaller discounts. The 9.1 percent lower cost for placements with single buyers is consistent with the view that the cost of becoming informed (and/or expected monitoring cost) is partially offset by a control premium for the block. When we estimated the model substituting Change in ownership concentration for

\footnotetext{
${ }^{25}$ Discounts on restricted shares, though commonly characterized as "liquidity" discounts are unlikely to be due entirely to the two-year restriction on resale under SEC Rule 144. Liquidity discounts of such magnitudes would provide strong incentives for firms to register their shares prior to issuing or to commit to quickly register shares after the private sale. Given the substantial resources of institutions that do not value liquidity highly such as life insurance companies and pension funds, it is not obvious that investors would require substantial liquidity discounts just for committing not to resell quickly.
} 
Single investor, we found similar results except that the coefficient on Fraction placed was near zero and not significant, and the coefficient on Change in ounership concentration though negative, had a $p$-value of 0.24 . Because of missing data on ownership concentration, the sample size for our estimate of the alternative specification was reduced to 70. Excluded observations tended to be large placements by smaller firms, placements of restricted shares, and placements by firms facing financial distress.

We find no significant relationship for private sales to Management buyers. It appears managers pay prices similar to those for sales to outsiders. As discussed above, we had no expectation for the sign of this relationship.

In Table VIII, discount-adjusted abnormal returns are analyzed by weighted least squares, where the observations are weighted by the reciprocal of the residual variance obtained from estimating the market model. Our findings are consistent with the prediction of more positive information effects when firms are subject to greater potential for undervaluation. We find more positive returns when Fraction placed is large and when Book-to-marketequity is low. The coefficient on Financial distress, though correctly signed, is not significant. Firm size also is not significant. Again, we estimated the model substituting Speculative product for Book-to-market-equity. The resulting coefficient on Speculative product was 8 percent with a $p$-value of 0.02 . In that specification, the coefficient on Financial distress increased to 5.1 percent but still was not significant. The significance levels of other variables were unaffected.

Evidence on whether limiting opportunistic resale provides a more credible signal of firm value is provided by the Restricted shares and Single investor coefficient estimates. Consistent with expectations we find that sales of Restricted shares are associated with an additional 7.8 percent positive stock price effect ( $p$-value $=0.07$ ). Sales to Single investors, however, do not yield a significant information effect. This result is most consistent with the control premium explanation for the discount, but with no material signaling (or incremental monitoring) benefit. We found a similar result when we estimated the model substituting Change in ownership concentration for Single investor. The coefficient on Change in ownership concentration was negative and not significant, and the coefficient on Restricted shares declined in significance due to the unavailability of ownership data for most of the firms placing restricted shares.

Finally, contrary to our expectations, placing shares with management does not convey significantly less positive information than placing with outside parties. However, since our sample includes only 6 placements with management, the test is weak. ${ }^{26}$

\footnotetext{
${ }^{26}$ In Table VI we show that discounts and discount-adjusted abnormal returns are smaller for placements with foreign investors. To test whether differences are accounted for by our models, we added Foreign investor as an additional explanatory variable. After controlling for the other variables in the models, neither relationship was statistically significant. The results imply that the type of investor is endogenous and depends on other aspects of the placement, i.e., placements where information costs are large (or monitoring benefits are important) tend to be placed with domestic investors.
} 


\section{B. Evidence on Ownership Structure Effects}

As a further effort to discriminate between information and monitoring effects we interact the Single investor indicator variable with the independent variables expected to be related to monitoring benefits and costs. The interaction approach is based on the premise that the likelihood of increased monitoring is expected to be higher when ownership of the privately placed shares is concentrated. Thus, expected signs of the interaction terms under the monitoring hypothesis are the same as for the corresponding independent variables. In the discount regression, the interaction terms allow us to test whether the size of the discount is related to the expected cost of monitoring. Since none of the interacted variables was significant at even the 20-percent level, and since other relationships in the model were virtually unchanged, we do not present these results.

Results of the interaction tests for the discount-adjusted returns model are presented as Model 1 in Table IX. Only the interaction of Restricted shares is significant at the 5-percent level and correctly signed. Since the noninteracted coefficient on Restricted shares loses significance in this specification, the result suggests that the benefit of restricting resale derives more from a commitment to monitor than from increased credibility of the information signal. We also estimated this model substituting Change in ownership concentration for Single investor. None of the interacted variables in that model was significant at the 10-percent level or better.

Table IX also contains the results of our investigation of the relation between changes in firm value and changes in ownership concentration around private sales of equity. In Model 2 we add Ownership concentration and Change in ownership concentration to our basic model. Model 3 is a piecewise linear regression of a specification similar to those of Wruck and Morck, Shleifer, and Vishny with turning points of 5 percent and 25 percent. The ownership variables in both models are constructed following the procedure in Wruck. The Single investor variable is excluded from these models since it is correlated with Change in ownership concentration. As indicated in the table, none of the change in ownership concentration variables is statistically significant. We also tried estimating the relation between changes in firm value and changes in ownership concentration excluding the other independent variables. Results were similar to those appearing in the table.

\section{Conclusion}

The market reaction to private sales of equity can reflect resolution of information asymmetries and/or anticipated effects of ownership structure changes. The information hypothesis, which we develop as an extension of Myers and Majluf, implies that changes in firm value around private placements can be driven by shifts in the market's assessment of the value of existing firm assets and investment opportunities. The ownership structure hypothesis, in contrast, implies that market revaluation can be a result of 
Table IX

\section{Evidence on Ownership Structure Effects from Cross-Sectional Regressions of Discount-Adjusted Abnormal Returns}

The dependent variable is the discount-adjusted return over the interval from 3 days before to the day of the announcement. Observations are weighted by the reciprocal of the residual variance obtained from estimating the market model. The sample includes 106 private placements between $1 / 1 / 80$ and $5 / 31 / 87$. Because of unavailability of data there are 70 observations for the regressions that include ownership concentration variables. All variables are defined in Table I.

\begin{tabular}{|c|c|c|c|c|}
\hline \multirow[b]{2}{*}{ Independent Variables } & \multirow[b]{2}{*}{$\begin{array}{l}\text { Predicted } \\
\text { Sign }\end{array}$} & \multirow[b]{2}{*}{$\begin{array}{c}\text { Monitoring } \\
\text { Effects } \\
\text { (Model 1) }\end{array}$} & \multicolumn{2}{|c|}{ Ownership Concentration Effects } \\
\hline & & & $\begin{array}{c}\text { Linear } \\
\text { Regression } \\
\text { (Model 2) }\end{array}$ & $\begin{array}{c}\text { Piecewise } \\
\text { Regression } \\
\text { (Model 3) }\end{array}$ \\
\hline Intercept & & 0.066 & 0.171 & 0.049 \\
\hline Fraction placed & & $0.627^{\mathrm{a}}$ & $0.510^{\mathrm{a}}$ & $0.469^{a}$ \\
\hline Financial distress & & $0.075^{b}$ & $0.140^{\mathrm{a}}$ & $0.077^{\mathrm{b}}$ \\
\hline Firm size & & -0.004 & -0.008 & -0.000 \\
\hline Book-to-market-equity & & $-0.057^{b}$ & $-0.088^{\mathrm{a}}$ & $-0.109^{a}$ \\
\hline Restricted shares & & 0.036 & -0.036 & -0.009 \\
\hline Single investor & & 0.253 & & \\
\hline Management buyer & & $-0.085^{\mathrm{d}}$ & -0.073 & $-0.190^{\mathrm{a}}$ \\
\hline $\begin{array}{l}\text { Fraction placed } * \text { Single } \\
\text { investor }\end{array}$ & $(+)$ & -0.302 & & \\
\hline $\begin{array}{l}\text { Financial distress * Single } \\
\text { investor }\end{array}$ & $(+)$ & $-0.111^{\mathrm{d}}$ & & \\
\hline $\begin{array}{l}\text { Firm size } * \text { Single investor } \\
\text { Book-to-market-equity } *\end{array}$ & $(-)$ & -0.012 & & \\
\hline Single investor & $(-)$ & -0.029 & & \\
\hline $\begin{array}{l}\text { Restricted shares * Single } \\
\text { investor }\end{array}$ & $(+)$ & $0.258^{\mathrm{b}}$ & & \\
\hline $\begin{array}{l}\text { Ownership level } \\
\Delta \text { Ownership }\end{array}$ & & & $\begin{array}{l}-0.075^{\mathrm{d}} \\
-0.089\end{array}$ & \\
\hline $\begin{array}{l}\Delta \text { Ownership } \\
\Delta \text { Ownership }_{1}\end{array}$ & & & & -0.203 \\
\hline$\Delta$ Ownership $_{2}$ & & & & -0.040 \\
\hline$\Delta$ Ownership $_{3}$ & & & & 0.017 \\
\hline Number of observations & & 106 & 70 & 70 \\
\hline$F$-value & & 9.75 & 8.03 & 7.17 \\
\hline Adjusted $R^{2}$ & & $50.0 \%$ & $44.9 \%$ & $44.6 \%$ \\
\hline
\end{tabular}

$a, b, c, d$ denote significance (using a two-tailed test) at the $1 \%, 5 \%, 10 \%$, and $20 \%$ levels, respectively.

anticipated changes in managerial performance. This dichotomy suggests that firms may turn to equity private placements to finance valuable investment opportunities when financial slack is limited or to improve managerial performance even when financial slack is not a constraint on investment.

We investigate these explanations by analyzing private placement discounts and announcement effects for a sample of private sales of equity by 
exchange-listed and NASDAQ firms. Consistent with the information hypothesis, we find evidence that discounts reflect costs incurred by private investors to assess firm value and that abnormal returns reflect favorable inside information about the firm. Discounts are positively related to variables that proxy for the costs and expected benefits of becoming informed and information effects are related to factors bearing on the size of the potential asymmetry. Consistent with the ownership structure hypothesis, we also find some evidence that private placement discounts reflect compensation to private investors for expected rnonitoring services and that stock price effects reflect that expected benefit of increased monitoring. However, for our sample of private placements information effects appear to be more important. This conclusion is based on results of our tests to discriminate between information and monitoring effects and on an analysis of changes in ownership concentration for the firms in our sample.

Our results contrast with those of Wruck, who, for a sample that includes only larger, exchange-listed firms, finds a significant cross-sectional relation between firm value changes and changes in ownership concentration. Whereas Wruck studies private placements made by firms with equity traded on a major exchange, our sample includes primarily smaller firms with share price data reported on NASDAQ. The differing findings suggest that the relative importance of private placements for resolving information asymmetries versus aligning managerial incentives may depend on firm size. This conjecture is based on the view that there are fundamental differences between small and large firms. Smaller firms tend to be growing and illiquid. Firms in our sample conform to this tendency as many are engaged in speculative product development or threatened with financial distress. Further, managerial share ownership in small firms, including those in our sample, tends to be high. Larger firms tend to be more liquid with lower managerial share ownership, suggesting that the benefits of increased monitoring or incentive alignment may be relatively more important.

In their conclusion, Morck, Shleifer, and Vishny note that ownership structure effects may be relatively less important for small firms as compared to the larger firms they study. Our findings are consistent with this view. Our evidence suggests that, for the smaller firms that comprise our sample, private sales of equity are primarily capital-raising events as opposed to ownership-restructuring events.

\section{REFERENCES}

Arneson, G. S., 1981a, Nonmarketability discounts should exceed fifty percent, Taxes 59, 25-31. 1981 b, Minority discounts beyond fifty percent can be supported, Taxes 59, 97-102.

Barclay, M. J., and C. G. Holderness, 1989, The private benefits of control of public corporations, Journal of Financial Economics 25, 371-395.

Bradley, M., and L. M. Wakeman, 1983, The wealth effects of targeted share repurchases, Journal of Financial Economics 11, 301-328.

Campbell, T. S., and W. A. Kracaw, 1980, Information production, market signaling, and the theory of financial intermediation, Journal of Finance $35,863-882$. 
Demsetz, H., and K. Lehn, 1985, The structure of corporate ownership: Causes and consequences, Journal of Political Economy 93, 1155-1177.

Dodd, P., and J. Warner, 1983, On corporate governance: A study of proxy contests, Journal of Financial Economics 11, 401-438.

Fama, E. F., and M. C. Jensen, 1983, Separation of ownership and control, Journal of Law and Economics 26, 301-325.

Fields, L. P., and E. L. Mais, 1991, The valuation effects of private placements of convertible debt, Journal of Finance 46, 1925-1932.

Friedlob, G. T., 1983, What are the effects of differing types of restrictions on closely-held stocks?, The Journal of Taxation 58, 240-243.

Giammarino, R. M., and T. Lewis, 1988, A theory of negotiated equity financing, Review of Financial Studies 1, 265-288.

James, C., and P. Wier, 1990, Borrowing relationships, intermediation and the cost of issuing public securities, Journal of Financial Economics 28, 149-171.

Jensen, M. C., and W. H. Meckling, 1976, Theory of the firm: Managerial behavior, agency costs and capital structure, Journal of Financial Economics 3, 305-360.

Johnson, R. D., and G. A. Racette, 1981, Discounts on letter stock do not appear to be a good base on which to estimate discounts for lack of marketability on closely held stocks, Taxes 59, 574-581.

Kato, K., and J. Schallheim, 1991, Public and private placements of seasoned equity issues in Japan, Working paper, University of Utah.

Leland, H. E., and D. H. Pyle, 1977, Information asymmetries, financial structure, and financial intermediation, Journal of Finance 32, 371-387.

Lucas, D. J., and R. L. McDonald, 1990, Equity issues and stock price dynamics, Journal of Finance 45, 1019-1043.

Mikkelson, W., and H. Regassa, 1991, Premiums paid in block transactions, Managerial and Decision Economics 12, 511-517.

Miller, M., and K. Rock, 1985, Dividend policy under asymmetric information, Journal of Finance 40, 1031-1051.

Morck, R., A. Shleifer, and R. Vishny, 1988, Management ownership and market valuation: An empirical analysis, Journal of Financial Economics 20, 293-315.

Myers, S. C., and N. S. Majluf, 1984, Corporate financing and investment decisions when the firm has information that investors do not have, Journal of Financial Economics 13, $187-221$.

Scholes, M., and J. Williams, 1977, Estimating betas from nonsynchronous data, Journal of Financial Economics 5, 309-327.

Securities and Exchange Commission, 1971, Institutional Investor Study Report (U.S. Government Printing Office, Washington, D.C.).

Shleifer, A., and R. Vishny, 1986, Large shareholders and corporate control, Journal of Political Economy 95, 461-488.

Silber, W. L., 1991, Discounts on restricted stock: The impact of illiquidity on stock prices, Financial Analysts Journal 47, 60-64.

Smith, C., 1986, Investment banking and the capital acquisition process, Journal of Financial Economics 15, 3-29.

Stulz, R. M., 1988, Managerial control of voting rights: Financing policies and the market for corporate control, Journal of Financial Economics 20, 25-54.

White, H., 1980, A heteroskedasticity-consistent covariance matrix estimator and a direct test for heteroskedasticity, Econometrica 48, 817-838.

Wruck, K. H.; 1989, Equity ownership concentration and firm value: Evidence from private equity financings, Journal of Financiai Economics 23, 3-28. 
Copyright of Journal of Finance is the property of Blackwell Publishing Limited and its content may not be copied or emailed to multiple sites or posted to a listserv without the copyright holder's express written permission. However, users may print, download, or email articles for individual use. 